\title{
Communication
}

[Comunicação]

\section{Antimicrobial susceptibility of coagulase-negative Staphylococci isolated from mastitic cattle in Brazil}

\author{
[Susceptibilidade antimicrobiana de cepas de Staphylococci coagulase-negativa isoladas \\ de leite de bovinos com mastite no Brasil] \\ T.R.O. Machado ${ }^{1}$, M.G. Correa ${ }^{2}$, J.M. Marin $^{3 *}$ \\ ${ }^{1}$ Faculdade de Ciências Agrárias e Veterinárias - UNESP - Jaboticabal, SP \\ ${ }^{2}$ Laboratório Vitafort S.A - Ribeirão Preto, SP \\ ${ }^{3}$ Faculdade de Odontologia de Ribeirão Preto - USP \\ Avenida do Café $\mathrm{s} / \mathrm{n}$ \\ 14040-904 - Ribeirão Preto, SP
}

Mastitis is the most common and costly disease of dairy cows (Hortet and Seegers, 1998; Zafalon et al., 2007); this is also the single most common reason for antimicrobial use in dairy herds, since antimicrobial therapy is the major primary tool for mastitis control in lactating and dry cows. Recently, coagulase-negative Staphylococci (CNS) are increasing in importance as cause of bovine intramammary infection (IMI) all over the world. They have been isolated from milk samples collected from cows with clinical and subclinical mastitis in several countries (Aarestrup et al., 1995; Gentilini et al., 2002; Amaral et al., 2003).

Identification of mastitis pathogens is important for the selection of appropriate antimicrobial therapies; beta-lactam derived are frequently used. Bacterial resistance to such products can be due to the production of beta-lactamases and/or a low-affinity to penicillin-binding protein, PBP2a (Odd and Maeland, 1997). In recent years, antimicrobial resistance has been a growing concern worldwide (Overcoming..., 2000). When a growing proportion of bacteria develop resistance, effectiveness of current treatments may be jeopardized, and resistant bacteria, present in food from animal species, may contaminate them and be transmitted to humans through the food chain (Donnely et al., 1996; Nader Filho et al., 2007). The objective of this

Recebido em 4 de abril de 2006

Aceito em 6 de dezembro de 2007

Autor para correspondência (Corresponding author)

E-mail: jmmarin@forp.usp.br study was to determine the in vitro susceptibility to 18 antimicrobial agents of CNS isolated from milk of bovines showing IMI, in Brazil.

Milk samples (752) from cows raised in nine Brazilian states (São Paulo, Minas Gerais, Espirito Santo, Goiás, Bahia, Pará, Paraná, Santa Catarina and Rio Grande do Sul) were aseptically collected from February to May 2005. The samples were submitted to the California Mastitis Test (CMT) proposed by Schalm and Noorlander (1957). CMT-positive milk samples were refrigerated to about $4^{\circ} \mathrm{C}$, and immediately delivered to the laboratory of "Genética $\mathrm{e}$ Morfologia, Departamento de Estomatologia e Fisiologia, Universidade de São Paulo Campus, Ribeirão Preto, for analysis. For that, they were plated on bovine blood agar (Columbia agar ${ }^{1}$, CM 331 supplemented with 5\% sterile bovine blood) and on Baird Parker agar ${ }^{1}$ and incubated for $24-48 \mathrm{~h}$ at $37^{\circ} \mathrm{C}$. Grampositive, catalase-positive, rabbit plasma coagulase-negative or positive cocci, were biochemicaly confirmed as Staphylococci when they produced acid from sucrose, maltose, mannitol and trehalose, but not from xylose (Gahrn-Hansen et al., 1987).

The scheme proposed by Kloos and Schleifer, and modified by Bannerman (2003) is conventionally used to classify $\mathrm{CNS}$ isolates at the species level; however, in the present study,

${ }^{1}$ Oxoid - Basingstoke, UK 
the simplified method proposed by Cunha et al. (2004) was used.

Antimicrobial susceptibility was tested by the Kirby-Bauer disk diffusion method with Mueller Hinton agar, using the following antimicrobial impregnated disks ${ }^{2}$ (Cefar-São Paulo, BR): amoxicillin/clavulanic acid; ampicillin; bacitracin; kanamycin; cefalexin; erythromycin; streptomycin; gentamicin; neomycin; lincomycin; nitrofuranthoin; novobiocin; oxacillin; penicillin; sulphonamide; sulfamethoxazole/trimethoprim; tetracycline; cefotaxime. Zones of growth inhibition were evaluated according to NCCLS standards (Performance..., 2002). Oxacillin was included for detection of methicillin-resistance because it is more stable than methicillin and provides more reliable results (Performance..., 2002). Oxacillin resistance is reported to show resistance to all $\beta$ lactam antimicrobial agents. Staphylococcus aureus ATCC 25923 was used as a control in all assays.

From a total of 752 milk samples collected from February to May 2005, 109 (14.5\%) were positive for CNS. These strains are often referred to as minor mastitis pathogens. Some investigators have claimed that they may protect the udder from infections caused by major pathogens (Schukken et al., 1989). However, others have not observed this protection (Hogan et al., 1988). Accurate identification of CNS is needed in order to obtain an early prediction of the potential pathogenicity or antimicrobial susceptibility to ascertain the clinical significance of each species. Four species of CNS were identified among the 109 strains tested (Table 1). Among them, S. simulans was most frequently isolated $(94.5 \%)$. Other report (Bes et al., 2000) indicated $S$. chromogenes, $S$. epidermidis, S. hyicus, and $S$. simulans as the most common CNS species found in mastitis. But, in the present study, almost all isolates were $S$. simulans. The predominance of this species among the CNS is similar to the results reported by Birgersson et al. (1992).
Table 1. Frequency of coagulase-negative staphylococcal species from clinical and subclinical cases of bovine mastitis in Brazil

\begin{tabular}{lc}
\hline \multicolumn{1}{c}{ Species } & $\begin{array}{c}\text { Total number isolated } \\
(\%)\end{array}$ \\
\hline S. simulans & $103(94.6)$ \\
S. haemolyticus & $2(1.8)$ \\
S. warneri & $2(1.8)$ \\
S. cohnni & $2(1.8)$ \\
\hline Total & $109(100)$ \\
\hline
\end{tabular}

Mastitis is the single most common reason for the use of antimicrobials in dairy cattle husbandry. Therefore, antimicrobial resistance of mastitis pathogens has received much interest over the past few years. The in vitro activities of each of the antimicrobial agents tested against CNS are summarized in Table 2. All CNS tested isolates were resistant to at least one antimicrobial. The highest resistance was observed against penicillin (102/109-93.5\%), followed by resistance to sulphonamide (97/109$88.9 \%)$, novobiocin (96/109- 88.6\%) and ampicillin (93/109-85.3\%). Important resistance was also observed against oxacillin (88/109$80.7 \%)$ and lincomycin (83/109-76.1\%). Susceptibility of CNS isolated from bovine IMI to selected antimicrobial agents has been previously reported (Aarestrup et al., 1995; Gentilini et al., 2002; Amaral et al., 2003; Correa et al., 2005). Results with penicillin predict susceptibility or resistance to other $\beta$-lactamasesensitive antimicrobial agents, e.g. ampicillin. Penicillin-resistance found in this study is higher than that reported in studies conducted in Argentina (21.1\%) (Gentilini et al., 2002) and Denmark (36.1\%) (Aarestrup et al., 1995), but is similar to other results reported in Brazil (77.8\%) (Corrêa et al., 2005). The high number of Staphylococci isolates showing resistance to penicillin, ampicillin and lincomycin is similar to other Brazilian reports (Amaral et al., 2003; Corrêa et al., 2005) as also does that to sulphonamide (Corrêa et al., 2005). The high number of isolates showing methicillin (oxacillin) resistance (Table 2) is a serious cause of concern.

${ }^{2}$ Cefar - São Paulo, Brasil. 
Table 2. Antimicrobial susceptibility test of 109 Staphylococcus coagulase-negative strains, isolated from 752 milk samples obtained from mastitic cows in Brazil, from February - May 2005

\begin{tabular}{lcc}
\hline Antimicrobial agents & $\mathrm{N}^{\mathrm{o}}$ & $\%$ \\
\hline Amoxicillin/clavulanic acid & 51 & 46.7 \\
Ampicillin & 93 & 85.3 \\
Penicillin & 102 & 93.5 \\
Oxacillin & 88 & 80.7 \\
Bacitrin & 64 & 58.7 \\
Cefotaxime & 55 & 50.4 \\
Cefalexin & 84 & 77.0 \\
Erythromycin & 67 & 61.4 \\
Streptomycin & 69 & 63.3 \\
Kanamycin & 86 & 78.8 \\
Gentamicin & 48 & 44.0 \\
Neomycin & 64 & 58.7 \\
Lincomycin & 83 & 76.1 \\
Nitrofurantoin & 50 & 45.8 \\
Tetracycline & 75 & 68.8 \\
Novobiocin & 96 & 88.6 \\
Sulphonamide & 97 & 88.9 \\
Sulfamethoxazole/trimethoprim & 57 & 52.2 \\
\hline
\end{tabular}

$\mathrm{N}^{\mathrm{o}}=$ Number of isolates resistant; \% $\%$ Percentage of resistant isolates

Multidrug resistance was commonly found. Almost all isolates showed resistance to two or more drugs (Figure 1). The occurrence of multiresistant strains may be a response to the selective pressure caused by the abusive use of antimicrobials in animal practice (Donnely et al., 1996). In the present study, an alarming level of multidrug resistance was detected when compared with results of other authors. Oliveira et al. (2002) did not report any Staphylococcus isolate showing multidrug resistance. However, Corrêa et al. (2005) reported a high level of multi-resistance of $S$. aureus isolated from milk of mastitic bovine.

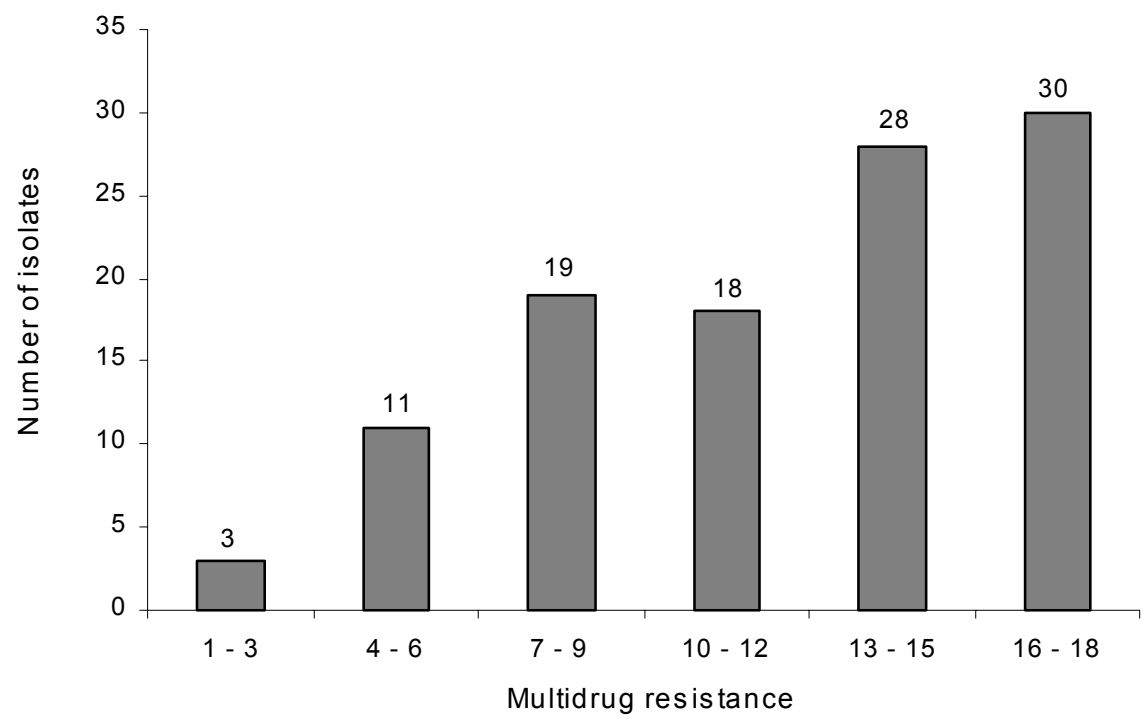

Figure 1. Distribution of multidrug resistance to 18 antimicrobial drugs among 109 isolates of coagulasenegative Staphylococcus isolated from milk samples of mastitic cows in Brazil (2005). 
The emergence and dissemination of antimicrobial resistance is the result of numerous complex interactions among antimicrobials, microorganisms, and the environment. There is growing evidence and little doubt that resistance genes can be spread and exchanged between different bacterial populations (McDermott et al., 2002).

The disk diffusion method of determining antimicrobial susceptibility, although widely used and economically attractive, has limitations. The interpretative criteria used for categorizing isolates as susceptible or resistant are based on human data. Thus, the NCCLS guidelines may not be appropriate to determine the antimicrobial susceptibility of bovine mastitis pathogens, and certainly can not be used to predict clinical efficacy of the drug for the treatment of bovine mastitis (Rajala-Schultz et al., 2004). In conclusion, coagulase-negative staphylococci isolated from milk of mastitic bovine showed high resistance to all antimicrobial drugs tested. The multidrug resistance was extremely high, and a cause for serious concern.

Keywords: coagulase-negative Staphylococci, antimicrobial resistance, bovine mastitis.

\section{RESUMO}

Um total de 109 cepas de Staphylococci coagulase-negativa foi isolado de leite de vacas com mastite clínica e subclínica, em 35 fazendas, situadas em nove estados brasileiros, no período de fevereiro a maio de 2005. Os isolados foram investigados em relação a susceptibilidade in vitro a diversos agentes antimicrobianos. A resistência à penicilina foi a observação mais freqüente (93,5\%), seguida por sulfonamida (88,9\%), novobiocina (88,6\%) e ampicilina (85,3\%). Todas as cepas examinadas mostraram resistência a pelo menos uma das drogas antimicrobianas testadas. Cepas apresentando resistência múltipla foram extremamente comuns, com 10,0\% dos microrganismos isolados apresentando resistência a todas as drogas antimicrobianas. Os resultados obtidos indicaram que as cepas de Staphylococci coagulase-negativas, isoladas no Brasil, apresentaram um alto grau de resistência a antimicrobianos. Estes resultados são, provavelmente, uma conseqüência da pressão devida ao uso intensivo de drogas antimicrobianas.

Palavras chave: Staphylococci coagulase-negativa, resistência antimicrobiana, mastite bovina

\section{ACKNOWLEDGEMENTS}

The authors thank the laboratory Vitafort for the strains supplied.

\section{REFERENCES}

AARESTRUP, F.M.; WEGENER, H.C.; ROSDAHL, V.T. et al. Staphylococcal and other bacterial species associated with intramammary infections in Danish herds. Acta Vet. Scand., v.36, p.475-487, 1995.

AMARAL, L.A.; ROSSI JUNIOR, O.D.; NADER FILHO, A. et al. Ocorrência de Staphylococcus sp em água utilizada em propriedades leiteiras do estado de São Paulo. Arq. Bras. Med. Vet. Zootec., v.55, p.1-9, 2003.

BANNERMAN, T.L. Staphylococcus, Micrococcus, and other catalase-positive cocci that grow aerobically. In MURRAY, P.R;
BARON, E.J; JORGENSE, J.H et al (Eds). Manual of Clinical Microbiology. Washington: American Society Microbiology, 2003. p.384404.

BES, M.; GUERIN-FAUBLEE, V.; MEUGNIER, $H$. et al. Improvement of the identification of staphylococci isolated from bovine mammary infections using molecular methods. Vet. Microb., v.71, p.287-294, 2000.

BIRGERSSON, A.; JONSSON, P.; HOLBERG, O. Species identification and some characteristics of coagulase-negative Staphylococci isolated from bovine udders. Vet. Microb., v.31, p.181-189, 1992.

CORREA, I.; CORREA, M.G.P.; MARIN, J.M. Antimicrobial susceptibility of strains of coagulase-positive Staphylococcus isolated from mastitic bovine milk. ARS Vet., v.21, p.69-76, 2005. 
CUNHA, M.L.R.S; SINZATO, Y.K. SILVEIRA, L.V.A. Comparison of methods for identification of coagulase-negative Staphylococci. Mem. Inst. Oswaldo Cruz, v.99, p.855-860, 2004.

DONNELY, J.P.; VOSS, A.; WHITE, A. et al. Does the use in animals of antimicrobial agents, including glycopeptide antibiotics influence the efficacy of antimicrobial therapy in humans? $J$. Antimicrob. Chemother., v.37, p.389-392, 1996.

GAHRN-HANSEN, B.; HELTBERG, O.; ROSDAHL, V.T. et al. Evaluation of a conventional routine method for identification of clinical isolates of coagulase-negative Staphylococcus and Micrococcus species. Acta Path. Microb. Immun. Scan. Bull., v.95, p.283292, 1987.

GENTILINI, E.; DENAMIEL, G.; BETANCOR, A. et al. Antimicrobial susceptibility of coagulase-negative Staphylococci isolated from bovine mastitis in Argentina. J. Dairy Sci., v.85, p.1913-1917, 2002.

HOGAN, J.S.; SMITH, K.L.; TODHUNTER, D.A. et al. Rate of environmental mastitis in quarters infected with Corynebacterium bovis and Staphylococcus species. J. Dairy Sci., v.71, p. $2520-2525,1988$

HORTET, P.; SEEGERS, H. Loss in milk yield and related composition changes resulting from clinical mastitis in dairy cows. Review Prev. Vet. Med., v.37, p.1-20, 1998.

McDERMOTT, P.F.; ZHAO, S.; WAGNER, D.D. et al. The food safety perspective of antibiotic resistance. Anim. Biotechnol., v.13, p.71-84, 2002.

NADER FILHO, A.; FERREIRA, L.M.; AMARAL, L.A. et al. Produção de enterotoxinas e da toxina da síndrome do choque tático por cepas de Staphylococcus aureus isoladas na mastite bovina. Arq. Bras. Med. Vet. Zootec., v.5, p.1316-1318, 2007.

ODD, G.B.; MAELAND, J.A. Mechanisms of methicilin resistance in staphylococci. AMPIS, v.105, p.264-276, 1997.

OLIVEIRA, A.A.F.; MOTA, R.A.; SOUZA, M.I. et al. Perfil de sensibilidade antimicrobiana in vitro frente a amostras de Staphylococcus spp. Isoladas de mastite subclinica bovina no agreste meridional de Pernambuco. A Hora Vet., v.127, p.8-10, 2002.

OVERCOMING antimicrobial resistance. WHO report on infections diseases, 2000. Disponível em: $\quad<\mathrm{http}: / / \mathrm{www}$.who.int/infectious-diseasereport/2000/index.html>. Acessado em $12 \mathrm{fev}$. 2006.

PERFORMANCE standards for antimicrobial disk and dilution susceptibility tests for bacteria isolated from animals. Wayne, PA: NCCLS, 2002. (NCCLS document M31-A2).

RAJALA-SCHULTZ, P.J.; SMITH, K.L.; HOGAN, J.S. et al. Antimicrobial susceptibility of mastitis pathogens from first lactation and older cows. Vet. Microbiol., v.102, p.33-42, 2004.

SCHALM, D.W.; NOORLANDER, D.O. Experiments and observation leading to development of the California Mastitis Test. $J$. Am. Vet. Med. Assoc., v.130, p.199-204, 1957.

SCHUKKEN, Y.H.; VAN DE GEER, D.; GROMMERS, F.J. et al. Intramammary infections and risk factors for clinical mastitis in herds with low somatic cell counts in bulk milk. Vet. Rec., v.125, p.393-396, 1989.

ZAFALON, L.F.; NADER FILHO, A.; OLIVEIRA, J.V. et al. Mastite subclínica por Staphylococcus aureus: custo-benefício da antibioticoterapia de vacas em lactação. Arq. Bras. Med. Vet. Zootec., v.59, p.577-585, 2007. 